\title{
Itinerário da sinodalidade na Igreja: das origens da Igreja à volta às fontes do Vaticano II
}

\author{
Itinerary of synodality in the church: \\ From the origins of the church back \\ to the sources of Vatican II
}

\author{
Pedro Paulo das Neves* \\ Recebido: 04/10/2018. Aprovado: 17/10/2018.
}

Resumo: O presente artigo tem por objetivo despertaro interesse de conhecermelhor o caminho da sinodalidade eclesial e as resistências encontradas para o seu desenvolvimento. Quer situar o resgate do Concílio Vaticano II e o desafio na concretização da renovação eclesiológica, na perspectiva de uma autêntica comunhão expressa no conceito de "Igreja-Povo de Deus". Pretende propor a teologia da Igreja Local e a prática de sínodos diocesanos para a reconfiguração das estruturas de comunhão e de participação de todos os membros eclesiais. Para isso, é indispensável conhecer o caminho que vai dos primeiros séculos ao Vaticano II.

Palavras-chave: Sinodalidade. Povo de Deus. Sínodo Diocesano. Igreja Local.

Abstract: The purpose of this article is to raise awareness of the path of ecclesial synodality and the resistance to its development. It wants to situate the rescue of the Second Vatican Council and the challenge in the concretization of the ecclesiological renewal, in the perspective of an authentic communion expressed in the concept of "Church-People of God". It intends to propose the theology of the Local Church and the practice of diocesan synods for the reconfiguration of the structures of communion and participation of all the ecclesial members. For this, it is indispensable to know the path that goes from the first centuries to Vatican II.

Keywords: Synodality. God's people. Diocesan Synod. Local Church.

* Doutorando em Teologia (Universidade Católica do Paraná, Curitiba, 2018). Mestre em Teologia (Université Catholique de Louvain, Louvain-la-Neuve-Bélgica, 2008). Especialização em Teologia Bíblica (Instituto de Teologia Pastoral, Passo Fundo, 2003). Licenciatura em Filosofia, Sociologia e Psicologia (Universidade do Sul de Santa Catarina, Tubarão, 1993). Bacharel em Teologia (Instituto Teológico de Santa Catarina, Florianópolis, 1997).

E-mail: pepauloneves@hotmail.com 


\section{Introdução}

A eclesiologia conciliar faz o caminho da história para chegar aos fundamentos da transformação que há muito tempo já vinha sendo gestada pelas forças vivas dentro e fora da Igreja. Os alicerces bíblicos e patrísticos são abundantes nos posicionamentos teológicos, os quais trarão à luz do dia o grande acontecimento do Vaticano II. Na linhagem que culminou com Concílio Vaticano II, a comunidade teológica é estimulada a uma cientificidade maior de seu saber, interessando-se mais pelos ensinamentos da história dos primeiros séculos do cristianismo. A análise documental da história dos sínodos diocesanos nos tempos passados favorece a compreensão do itinerário da sinodalidade da Igreja, desde as origens até o Vaticano II.

\section{Os sínodos nas igrejas locais}

O caminho sinodal na vida da Igreja foi feito de altos e baixos. A intuição sinodal remonta mesmo à experiência do povo de Deus do Primeiro Testamento e à sua passagem para as novas comunidades surgidas à sombra do Mistério Pascal, como descrito na Escritura e testemunhado pela Tradição viva da Igreja. O desenvolvimento e a consciência desta realidade é algo que só se pode alcançar ao percorrer o caminho pontuando alguns momentos desta trajetória.

No primeiro milênio da Igreja, a sinodalidade teve uma marca mais acentuada. É neste período que o desenvolvimento das Igrejas Locais e a prática dos sínodos diocesanos foram solidificados. Tanto na Igreja neotestamentária como na Igreja dos primeiros séculos e, mesmo em períodos mais comprometidos com o poder temporal de religião do Estado, ainda assim, a presença da sinodalidade foi decisiva na consciência eclesial.

\subsection{Os primeiros sínodos diocesanos}

Para compreender como surgiram e se desenvolveram os primeiros sínodos no itinerário histórico da Igreja e, de modo muito especial na Igreja antiga, se faz necessário passar os olhos sobre a maneira como era exercido o ministério do bispo dentro de uma comunidade e deste com os demais bispos em suas respectivas Igrejas. Fez-se um longo caminho até chegar à compreensão que se tem hoje. Há abundantes evidências de que os bispos, na Igreja Primitiva, tinham consciência de compartilhar a 
responsabilidade pela Igreja como um todo. Como disse São Cipriano: "Só há um episcopado, mas espalhado entre a multidão sinfônica de todos os numerosos bispos." Este vínculo de unidade foi bem expresso no requisito de que pelo menos três bispos devem tomar parte na ordenação (kirotonia) de um novo bispo ${ }^{2}$. Era também evidente nas várias reuniões de bispos, em concílios ou sínodos em que punham em discussão comum questões de doutrina (dogma, didaskalia) e prática, bem como em suas várias comunicações epistolares e mútuas visitas.

Já durante os primeiros quatro séculos, emergiram vários grupos de dioceses dentro de determinadas regiões. $\mathrm{O}$ (protos) primeiro entre os bispos da região era bispo da primeira sé, a metrópole, e seu ofício como metropolita sempre esteve vinculado aquela sé. Os concílios ecumênicos atribuíram certas prerrogativas (presbeia, pronomia, dikaia) ao metropolita, sempre no âmbito da sinodalidade. Assim, o primeiro Concílio Ecumênico (Niceia, 325) exigiu de todos os bispos de uma província sua participação pessoal, ou acordo por escrito, para uma eleição episcopal e consagração, um ato sinodal por excelência, e atribuíu ao metropolita a validação (kyros) da eleição de um novo bispo ${ }^{3}$. O quarto Concílio Ecumênico (Calcedônia, 451) evocou novamente os direitos (dikaia) do metropolita, insistindo ser este um ofício eclesial, não político ${ }^{4}$, como fez também o sétimo Concílio Ecumênico (Niceia II, 787).

O Concílio de Niceia II (787) oferece uma descrição canônica da correlação entre o protos e os outros bispos da região: "os bispos do povo de uma província ou região (ethnos) devem reconhecer quem é o primeiro (protos) entre eles e considerá-lo como sua cabeça [kephale], e não fazer

SÃO CIPRIANO, Ep. 55, 24, 2; cf. também: 'episcopatus unus est cuius a singulis in solidumparstenetur' (De unitate, 5).

2 PRIMEIRO CONCÍLIO ECUMÊNICO (Niceia, 325), cânone 4: "é preferível que um bispo seja estabelecido por todos os bispos de uma província; mas se isto parecer difícil em razão de alguma premente necessidade, ou da distância a ser percorrida, que pelo menos três bispos estejam juntos; e, tendo o consentimento por escrito dos bispos ausentes, podem então proceder a consagração. A validação [kyros] do ato ocorrido recai sobre a metropolita de cada província". Cf. também cânone apostólico, 1: "um bispo deve ser ordenado por dois ou três bispos".

3 PRIMEIRO CONCÍLIO ECUMÊNICO (Niceia, 325), cânone 4; também cânone 6: "Se alguém se torna um bispo sem o consentimento do metropolita, este grande concílio decreta que tal pessoa não é um bispo".

4 QUARTO CONCILIO ECUMÊNICO (Calcedônia, 451), cânone 12: "Quanto às cidades já honradas com o título de metrópole por cartas imperiais, que tais cidades e os bispos que as governam desfrutem apenas da honra do título; ou seja, que os direitos próprios a uma metrópole [kataaletheian] sejam salvaguardados". 
nada que seja importante sem o seu consentimento (gnome); cada bispo só pode fazer o que diz respeito à sua própria diocese (paroikia) e seus territórios dependentes. O primeiro [protos], por sua vez, não pode fazer nada sem o consentimento de todos. Desta forma prevalecerá a concórdia [homonoia], e Deus será louvado pelo Senhor no Espírito Santo"5.

A instituição do metropolitato é uma forma de comunhão regional entre as Igrejas Locais. Posteriormente, desenvolveram-se outras formas, nomeadamente os patriarcados, que compreendem vários metropolitatos. O metropolita e o patriarca são bispos diocesanos com poder episcopal em suas próprias dioceses. Nos assuntos relacionados às suas respectivas metrópoles ou patriarcados, no entanto, deverão agir em concordância com seus irmãos no episcopado. Esta forma de agir é a raiz da instituição sinodal, no sentido estrito do termo, como um sínodo regional. Os sínodos são convocados e presididos pelo metropolita ou pelo patriarca. Ele e todos os bispos atuam em mútua complementaridade e são responsáveis pelo sínodo.

Pensar a sinodalidade na Igreja Local e o sínodo diocesano na Igreja dos primeiros séculos é, necessariamente, referir-se ao processo de expansão do cristianismo dos primeiros séculos da cristandade. Tal postura remete a uma reflexão sobre a estrutura de organização do conjunto de ideias e práticas que se desenvolviam nas primeiras comunidades cristãs. $\mathrm{O}$ cristianismo primitivo pode ser dividido em duas fases distintas: o período apostólico, quando os primeiros apóstolos estavam vivos e propagaram a fé cristã; e o período pós-apostólico, quando foi desenvolvida uma das primeiras estruturas episcopais, quando houve uma intensa perseguição aos cristãos. Essa perseguição terminou em 313 sob o governo de Constantino I, que em 325 promulgou o primeiro concílio de Niceia, dando início à série dos Concílios Ecumênicos ${ }^{6}$.

Na sua etimologia, a palavra sínodo tem origem no grego synodos, e quer dizer "caminhar juntos". Um sínodo diocesano é uma "assembleia de eclesiásticos" e leigos "convocados pelo seu prelado ou outro superior" que se reúnem com o propósito de "caminhar juntos", seguindo um determinado plano. Para muitos estudiosos, a obra de Eusébio de Cesareia, "História Eclesiástica", é um marco na composição do que

5 CONCÍLIO DE ANTIOQUIA (327), cânone 9: "É apropriado aos bispos em cada província [eparquia] que se apresentem ao bispo que preside na metrópole".

6 LIMA, L. A. Sínodo dos bispos. In: Dicionário do Vaticano II. São Paulo: Paulinas; Paulus, 2015. p. 910. 
possivelmente poderia chamar uma historiografia de cunho religioso, atinada a uma perspectiva cristã. Foi a partir dele que a palavra sínodo se converteu em termo técnico para descrever as assembleias eclesiásticas. Uma sistematização da história dos sínodos em três etapas pode ser útil para entender melhor seu desenvolvimento e sua presença na Igreja antiga: da era apostólica até o Concílio de Trento; de Trento ao Código de 1917; e do Código de 1917 às reformas do Concílio Vaticano II e à elaboração do Código de 1983.

Sem dúvidas, a prática sinodal remonta aos primeiros séculos da história da Igreja. Alguns autores definem a origem do sínodo no chamado primeiro Concílio de Jerusalém (At 15,18), no ano 49. Quanto à atividade da prática de sínodos nos primórdios do cristianismo, acha-se importante estar atento à posição de Marcello Semeraro ${ }^{7}$ que diz:

Há testemunhos de atividade sinodal já entre os anos 160 e 175, na Ásia Menor, para discutir e resolver a questão montanista. A prática sinodal certamente originou-se da necessidade sentida pelos Bispos de consultarem um ao outro sempre que os problemas assumiam alcance mais amplo que o do local, mas também da sua consciência de constituir um Corpo episcopal encarregado de guardar a tradição apostólica.

Segundo Semeraro, Santo Agostinho distinguia três espécies de Sínodos: universal, regional e provincial. A eles se acrescentou no século IV o sínodo diocesano, composto pelos presbíteros e clérigos de uma diocese reunidos pelo bispo ${ }^{8}$. Alguns autores consideram que o primeiro sínodo foi convocado no ano 155, em Roma, pelo Papa Aniceto ${ }^{9}$, para solucionar a dúvida da data da Páscoa. ${ }^{10}$ Depois deste vieram muitos outros nas mais variadas regiões para que houvesse o reconhecimento mútuo da fé católica e para regulamentar e resolver diferentes questões disciplinares. No parecer de Zito, a sinodalidade não impede que o ministério apostólico siga outro caminho que, embora diferente ${ }^{11}$, não deixa de convergir com aquele: a emergência e a afirmação da autoridade e da

7 SEMERARO, M. Sínodo. In: Lexicon: Dicionário Teológico Enciclopédico. São Paulo: Loyola, 2003. p. 705.

8 SEMERARO, 2003, p. 706.

9 Outros indicam como primeiro sínodo o convocado pelo Papa Vítor em 190.

10 CHIRON, Y. Histoire des conciles. Paris: Pérrin, 2011, p. 6.

11 ZITO, G. La figura del vescovo lungo i secoli. Profilo storico fino al Concilio Vaticano I. In: PERI, V. (Ed.). La comunione con il vescovo. Profili storici, biblici, teologici. Roma: Unione Apostolica del Clero, 2009. p. 16. 
figura dos bispos como expressão da Tradição e da unidade da fé eclesial. Pode-se observar, por exemplo, em Eusébio, que ele faz referências às figuras episcopais mais salientes na sua História Eclesiástica, como bem assinalou Jean Daniélou ${ }^{12}$.

O primeiro sínodo diocesano de que temos notícia é o de Auxerre, por volta de 581-605, que reuniu 7 abades, 34 presbíteros e 3 diáconos, à volta do Bispo Aunachario (Aunaire), ${ }^{13}$ tendo sido promulgados 45 cânones, a maioria deles referentes a matéria litúrgica. De então para cá, o fenômeno dos sínodos diocesanos não deixou nunca de estar presente na vida da Igreja, em particular na Idade. ${ }^{14}$ Segundo Paiva ${ }^{15}$, os sínodos diocesanos eram

assembleias que congregavam o clero de um arcebispado, ou bispado, convocado pelo respectivo prelado, com o intuito de se avaliar o estado da vida religiosa, a situação clerical e de se proporem medidas de atuação nesses domínios. Eram ainda, em função de juntarem a totalidade do clero beneficiado - algum dele habitualmente residente em regiões periféricas das sedes diocesanas - um meio de transmissão de informações e normas oriundas dos diversos niveis de poder da Igreja.

Essas reuniões, a princípio, manifestavam a unidade do presbitério reunido em torno do bispo. ${ }^{16}$ É possível que o sínodo diocesano seja uma evolução do antigo presbitério que os apóstolos constituíram nas Igrejas, isto é, um colégio de padres com a responsabilidade de celebrar a Eucaristia e governar os fiéis. ${ }^{17}$

\section{Sinodalidade na unidade da Igreja}

Durante o primeiro milênio, a Igreja, no Oriente e no Ocidente, estava unida na preservação da fé apostólica, mantendo a sucessão apos-

12 DANIÉLOU, J. Des origines à la fin du troisième siècle. In: ROGIER, L. J.; AUBERT, R.; KNOWLES, M. D. Nouvelle histoire de l'Eglise, I. Paris: Du Seuil, 1963. p. 139-140.

13 TRICHET, L. Le Synode Diocesain. Paris: Cerf, 1992. p. 23.

14 PAIVA, J. P. Sínodos diocesanos. I Época medieval e moderna. In: AZEVEDO, C. (Ed.). Dicionário de história religiosa de Portugal IV. Lisboa: Círculo de Leitores, 2000. p. 240-241.

15 PAIVA, 2000, p. 240-241.

16 GHIRLANDA, G. O Direito na Igreja: mistério de comunhão: compêndio de direito eclesial. Aparecida: Santuário, 2003.

17 CABALLERO, J. El Sínodo Diocesano: breve recorrido a sua actuacion y evolucion histórica. Ius Canonicum, Pamplona, v. 21. n. 42, p. 543-566, 1981. 
tólica dos bispos, desenvolvendo estruturas de sinodalidade inseparavelmente vinculadas com a primazia e em uma compreensão da autoridade como serviço (diakonia) do amor.

Embora a unidade entre Oriente e Ocidente tenha, por vezes, sofrido perturbações, os bispos do Oriente e do Ocidente tinham a consciência de pertencer a uma só Igreja. Este patrimônio comum de princípios teológicos, provisões canônicas e práticas litúrgicas do primeiro milênio constitui um ponto de referência necessário e uma poderosa fonte de inspiração para católicos e ortodoxos que procuram curar a ferida da divisão gerada em 1054. Com base nesse patrimônio comum, ambos os lados devem considerar como a primazia, a sinodalidade e a inter-relação entre elas podem ser concebidas e exercidas hoje e no futuro.

A autoria e o modo da convocação dos sínodos e/ou concílios também foi sofrendo transformações ao longo dos séculos. Bispos, papas, imperadores e reis exerceram esta missão em tempos e contextos específicos. A referência ao poder determinou muitas vezes de quem era o direito. Nos primeiros séculos, os sínodos, apesar de parecidos com os concílios, são de natureza diferente, e são convocados em contextos muito diferentes. Nos primeiros séculos do cristianismo, os sínodos eram sinônimos de concílios regionais ou provinciais. Um concílio era convocado para dirimir dúvidas e/ou legislar sobre certas questões de teologia ou de disciplina. Uma vez convocado o concílio, marcava-se uma data para reunir seus participantes na cidade escolhida como sede e, quando todos ou a maioria dos participantes houvessem chegado, dava-se início aos trabalhos. A presidência costumava caber ao bispo da cidade, onde a reunião se realizava, ou ao mais velho entre os bispos participantes, ou ainda, ao mais respeitado entre os presentes. Muitas vezes esses três atributos estavam reunidos em uma mesma pessoa ${ }^{18}$.

Embora fossem os únicos a assinarem os cânones e as decisões conciliares, os bispos tinham muitas vezes como colegas diáconos, presbíteros, teólogos, leigos, sacerdotes, enviados especiais do imperador, ou outras autoridades. Há registro de bispos impedidos de viajar, que mandavam diáconos ou presbíteros como seus representantes. Havia, também, o caso de clérigos que participavam do concílio porque viviam nas proximidades e se interessavam pelos assuntos em debate. E havia,

18 CLERCQ, Ch. Histoire de Conciles d'après les documents originaux. Paris: Lrtouzey et Ané, 1949. t.11. 
ainda, os bispos que viajavam com séquitos de eclesiásticos, que os acompanhavam como corte ${ }^{19}$.

No contexto atual, apenas o bispo diocesano tem a faculdade de convocar um sínodo para a sua diocese: "Cân. 462. § 1. O sínodo diocesano convoca somente o bispo diocesano, e não aquele que preside interinamente a diocese" (AAS 75,1983-II, p. 84) ${ }^{20}$. Nenhum daqueles que governam a diocese interinamente, nem mesmo o Vigário Geral, com poderes especiais, poderá convocar um sínodo. Isso também acontece no caso da Sé vacante, "pois na vacância da Sé nada pode ser inovado na diocese" (Cân. 428, §1).

\subsection{A sinodalidade eclesial no final do primeiro milênio}

Ao longo do primeiro milênio, Oriente e Ocidente estavam unidos em certos princípios teológicos fundamentais acerca, por exemplo, da importância da continuidade na fé apostólica, da interdependência de primazia e conciliaridade/sinodalidade em todos os níveis da vida da Igreja, e na compreensão da autoridade como "serviço (diakonia) de amor", com "a recapitulação de toda a humanidade em Cristo Jesus" como meta (DR, nn.3-14). Mesmo quando a unidade do Oriente e do Ocidente passou, por vezes, por crises, os bispos do Oriente e do Ocidente estavam indefectivelmente conscientes de pertencer à mesma Igreja, e de ser sucessores dos apóstolos em um único episcopado. A colegialidade dos bispos expressava-se na vigorosa vida sinodal da Igreja em todos os níveis, local, regional e universal. Em âmbito universal, o bispo de Roma atuava como protos entre os chefes das sedes principais. Há muitos casos de apelações de vários tipos, feitas ao bispo de Roma, para promover a paz e manter a comunhão da Igreja na fé apostólica.

A experiência do primeiro milênio influenciou profundamente o curso das relações entre as Igrejas do Oriente e do Ocidente. Apesar da crescente divergência e de cismas pontuais durante este período, manteve-se ainda a comunhão entre o Oriente e o Ocidente. O princípio da diversidade na unidade, explicitamente aceito no Concílio de Cons-

19 HEFELE, C. J.; LECLERCQ, H. Histoire des Conciles, d'après les documents originaux. Paris: Librairie Lrtouzey et Ané, 1907. t. 4.

20 ACTAAPOSTOLICAE SEDIS, n. 75,1983, p. 84. 
tantinopla (879-880) conforme Denzinger ${ }^{21}$, tem especial relevância sobre a sinodalidade na Igreja Local. Várias diferenças de compreensão e interpretação não impediram ao Oriente e Ocidente de permanecer em comunhão. Houve um forte sentimento de ser uma Igreja e, determinação para seguir na unidade, como um só rebanho e um só pastor (Jo 10,16). O primeiro milênio é a tradição comum de nossas Igrejas. Em seus princípios teológicos e eclesiológicos básicos, esta tradição comum deve servir como modelo para a restauração da plena comunhão. A "diversidade não é sinônimo de divisão. Ainda que seja às vezes difícil de harmonizar", demandando certo esforço na busca do consenso ${ }^{22}$.

A Igreja Católica reconhece oito Concílios Gerais no primeiro milênio. Os seis primeiros estão ligados entre si, uma vez que os assuntos de um se arrastavam para o outro. Eles trataram de assuntos de ordem doutrinal e teológica, na definição das grandes verdades da fé, como a divindade e humanidade de Jesus, o mistério da Trindade, a relação entre Maria e Jesus. Os outros dois trataram de assuntos distintos, como o culto aos santos (Niceia II) e a estrutura interna da Igreja (Constantinopla IV). São eles: Niceia I (325), Constantinopla I (381), Éfeso (431), Calcedônia (451), Constantinopla II (553), Constantinopla III (680-681), Niceia II (787), Constantinopla IV (869-870).

\subsection{Concílios Provinciais/Sínodos Diocesanos}

Em relação a concílios provinciais, entre os séculos VI e VIII muitos determinaram a obrigação de se celebrar o sínodo diocesano ${ }^{23}$. São Bonifácio, no século VIII, deu grande impulso à atividade sinodal para controlar a formação do clero e também a cura pastoral ${ }^{24}$. Com a Reforma Carolíngia (Século VIII a IX), determinou-se a obrigação de se celebrarem os sínodos diocesanos como assembleias de clérigos e leigos, esses últimos sem voz, nem voto. O objetivo desses sínodos era a correção de abusos entre os fiéis leigos e clérigos. Gregório VII, na grande Reforma Gregoriana, procurou libertar a Igreja dos poderes seculares, inclusive nos concílios e nos sínodos, diminuindo a influência dos reis e de outras autoridades civis nesses eventos eclesiais.

\footnotetext{
1 DENZINGER, H. Compendio dos símbolos, definições e declarações de fé e moral. São Paulo: Paulinas; Loyola, 2013. DH-3055, p.661.

22 TILLARD, J. M. Église d'églises: L'écclésiologie de communio. Paris: CERF, 1987. p. 13.

23 CABALLERO, J., 1981, p. 549.

24 CABALLERO, J., 1981, p. 550-551.
} 
Diversos documentos testemunham a experiência sinodal nessa época, como o Capitula Episcoporum, um compêndio de disciplina sacramental elaborado por bispos dos séculos IX e X; os Ceremoniales, nos quais se regulamentava a forma como deveriam ser celebrados os sínodos; e o Decreto Graciano que, além de reconhecer a instituição sinodal, declarava-a como meio eficaz para corrigir costumes dos clérigos, impor a disciplina eclesiástica e fazer conhecidas aos leigos as decisões dos concílios provinciais ${ }^{25}$. Esses documentos demonstram, ao mesmo tempo, a constância da celebração dos sínodos, como também a sua característica marcadamente legislativa. Para Domenico Mogavero, "uma estabilidade do sínodo diocesano é localizada em torno do século IX, com a caraterística principal de ser quase caixa de ressonância da tarefa de legislar do bispo" 26 .

\subsection{Da sinodalidade ao primado jurisdicional}

Nos primeiros séculos, não havia a noção de um primado universal com repercussões jurisdicionais. Os concílios realizados ao longo dos séculos IV e V tiveram a participação da Igreja de Roma. No entanto, a sua função era apenas de assegurar a comunhão do Ocidente latino com todas as Igrejas orientais, até porque o Bispo de Roma nunca participou pessoalmente nesses concílios, limitando-se a enviar uma delegação.

No seu desenvolvimento histórico, a primazia de Roma sustenta-se tendo como pano de fundo a necessidade de uma Igreja una, assente na comunhão entre as várias Igrejas. Desde o início, mas sobretudo com a expansão do cristianismo tornou-se necessário manter relações vitais entre as Igrejas; assim Roma foi se assumindo como o centro desta solicitude por todas as Igrejas. Essa importância foi reconhecida igualmente pelo Concílio de Niceia (325), que definiu as três sedes apostólicas (Roma, Alexandria e Antioquia) e fez remontar a tríplice proeminência à figura de Pedro. No seio destas, a posição de Roma prevalece como a mais importante para a Igreja Universal, na abordagem das grandes controvérsias e nas discussões teológicas, sobretudo depois do Concílio de Constantinopla (381) ter atualizado a organização eclesiástica ao constituir a pentarquia, ou seja, a ordem hierárquica das sedes apostólicas

25 CABALLERO, J., 1981, p. 549-550.

26 MOgAVERO, D. II Sinodo Diocesano. In: LONGHITANO, A. et al. Chiesa Particulare e strutture di comunione. Bologna: EDB, 1985. p. 55. 
(que viu o número ser alargado a Jerusalém, em 325, e Constantinopla, em 381), onde Roma é sempre colocada em primeiro lugar ${ }^{27}$. Além da função de Bispo de Roma, o papa é também declarado Patriarca do Ocidente. Já antes, no Sínodo de Sárdica (c. 343), que foi convocado fundamentalmente para debater a questão da autonomia do Oriente e do Ocidente, a Igreja de Roma foi tida como a mais relevante.

Ao Bispo de Roma foi atribuída a missão de desempenhar aquele papel que outrora coube à Jerusalém, isto é, ser intendente da mediação e da unidade eclesial. Além dessas premissas, Roma foi sendo, ao longo dos tempos primitivos, uma rocha firme no combate às heresias. Perante o risco de fragmentações doutrinais. Roma assumiu a vanguarda no processo de restabelecimento da comunhão, de consolidação das relações e de reformulação das fórmulas de fé, entretanto, deturpadas. Roma começou, paulatinamente, a ser encarada, sobretudo, como centro da communio eclesial. Mas a sua relevância efetiva tem como tônica o primado na fé e na caridade, que as restantes comunidades deviam imitar e seguir fielmente.

\subsection{Do primado jurisdicional a autonomia do Oriente}

O Oriente funcionava de forma autônoma em relação a Roma. Mas, mesmo no Ocidente, nem sempre persistiu esta aceitação da Igreja de Roma como autoridade magisterial suprema, embora se sublinhasse um peso e uma auctoritas maiores em questões de fé. Desse modo, a teologia ortodoxa considera que o ministério de Pedro deve ser enquadrado no âmbito de outras realidades que tiveram uma função análoga no conjunto da vida da Igreja. O núcleo deste ministério, é o serviço à unidade e comunhão das Igrejas ${ }^{28}$. Ao olhar a Igreja desde o início, verifica-se que este não foi o único instrumento de serviço à comunhão. Há que ter presente também a realidade dos sínodos como instrumento de comunhão, e isso é fundamental na aceitação de um primado que não se situe numa perspectiva institucional autônoma, mas que olhe sempre numa ótica de conjunto e de diálogo com os irmãos no episcopado. Esta

\footnotetext{
$\overline{27}$ LIMA, 2015, p. 909-910.

28 TILLARD, J. M. El obispo de Roma: studio sobre el papado. Madrid: Sal Terrae, 1986. p. 19-20.
} 
é a perspectiva de Anne M. Vannier para um primado em sintonia com a colegialidade no seio da Sinodalidade eclesial ${ }^{29}$.

Neste contexto, a assembleia de Jerusalém (At 15) reveste-se de um especial significado na definição daquilo que pode ser o papel do papa enquanto "Sucessor de Pedro", ou seja, exercendo o seu ministério de moderador e de voz privilegiada, mas sem assumir a totalidade das rédeas da vida da Igreja, numa atitude de ausência de diálogo com as restantes Igrejas e seus bispos.

\section{A sinodalidade eclesial em declínio}

$\mathrm{O}$ poder romano foi crescendo desde os papas dos séc. IV e V, através das tensões com os concílios e das lendas do papa S. Silvestre e da "Doação de Constantino". Gregório Magno (590-604) tem importância nesse processo, como o verdadeiro primeiro papa medieval. A Igreja mantém estreita união com o Estado, de modo que, no Ocidente, ser cidadão era ser cristão, católico e romano. Tal modelo tem repercussões na liturgia, no canto gregoriano, na prática da confissão individual, no rigorismo da moral sexual. A partir de Gregório VII (Séc. XI) esse modelo se fortalece, ao estender o Papa, pelo Dictatus papae, seu poder sobre todo o mundo, com competência ilimitada. A centralização, o legalismo, a politização através do poder eclesiástico e seu domínio sobre todo o mundo, foram a consequência do caminho feito no segundo milênio ${ }^{30}$.

\subsection{Da comunhão à ruptura}

As igrejas do Oriente e do Ocidente se separaram no transcorrer de vários anos. O que um dia fora uma única Igreja paulatinamente se dividiu em duas identidades distintas. Diferenças quanto a detalhes insignificantes ampliaram o conflito. O Oriente usava o grego, ao passo que o Ocidente utilizava o latim, graças à Vulgata e aos teólogos ocidentais que escreveram nessa língua. As formas de culto eram diferentes: o pão usado na comunhão, assim como a data para a Quaresma e a maneira pela qual a missa deveria ser celebrada. No Oriente, o clero podia se casar e usava barba. Os sacerdotes ocidentais não podiam se casar e apresentavam o rosto completamente barbeado. As teologias eram di-

29 VANIER, M. A. Les pères et la naissance de l'ecclésiologie. Paris: CERF, 2009.

30 COMBLIN, J. O povo de Deus. São Paulo: Paulus, 2002. p. 56. 
ferentes. O Oriente se sentia desconfortável com a doutrina ocidental do purgatório. O Ocidente usava a palavra latina Filioque (e do Filho) no Credo niceno-constantinopolitano, depois de que a cláusula sobre o Espírito Santo estabelecera que o Espírito "procede do Pai". Para o Oriente, essa adição era heresia.

Diferenças que já existiam havia séculos, explodiram devido a dois homens de temperamento obstinado. Em 1043, Miguel Cerulário tornou-se Patriarca de Constantinopla. Em 1049, Leão IX tornou-se papa. Leão queria que Miguel, e por meio dele a Igreja oriental, se submetesse a Roma. O papa enviou representantes a Constantinopla, mas Miguel se recusou a encontrar-se com eles. Desse modo, os representantes excomungaram Miguel, em nome do papa. O patriarca respondeu fazendo o mesmo com os representantes do papa, excomungando-os.

Por meio de declarações recíprocas de que o outro não era verdadeiro cristão, os dois bispos criaram um cisma. Como dizia o Credo, os dois lados acreditavam "na Igreja una, santa, católica e apostólica". Em 1089, o Papa Urbano tentou fechar a ferida revogando a excomunhão do patriarca. Ele também promoveu a primeira cruzada, como meio de reunificar o Oriente e Ocidente, mas isso não deu certo. No coração da disputa estava a questão do poder. Em uma época que via a autoridade dos bispos como chave para a estabilidade da Igreja, não poderia haver duas pessoas reivindicando a mesma autoridade. Por não chegarem a um acordo, o Oriente e o Ocidente começaram a trilhar caminhos separados ${ }^{31}$.

A partir de 1088, um francês, que passou a ser conhecido por Urbano II, assumiu o cargo máximo da Igreja. Seu papado foi marcado por disputas com o rei alemão Henrique IV, uma continuação, infrutífera, das políticas reformistas de Gregório VII, o novo papa não estava plenamente disposto a continuar essa batalha. Em vez disso, queria unir toda a cristandade. À medida que os representantes do papa atravessavam a Europa, recrutando cavaleiros para ir à Palestina, recebiam entusiásticas reações dos guerreiros franceses e dos italianos. Muitos foram motivados por objetivos religiosos, mas, sem dúvida, outros se engajaram em função do ganho econômico e da aventura de recapturar os locais de peregrinação da Palestina, que haviam caído nas mãos dos muçulmanos.

Em muitos aspectos, as cruzadas deixaram um legado negativo. Elas ameaçaram as relações entre as igrejas do Ocidente e do Oriente, e

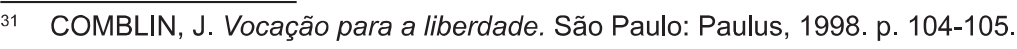


a brutalidade dos cruzados somente contribuiu para que seus inimigos se tornassem ainda mais fanáticos. Além disso, as lições que os cruzados aprenderam nos campos de batalha tornaram-se parte das estratégias para guerras futuras, promovidas contra outros cristãos.

A resposta ao chamado de Urbano incrementou grandemente o poder do papado. Ele conseguiu reunir um grande número de soldados, que estavam dispostos a morrer por sua fé, um feito que nenhum príncipe poderia ignorar. A luta pelo poder entre a Igreja e o Estado ainda não havia acabado. A Alta Idade Média trouxe o maior desafio para a fé católica, o surgimento de conflitos sobre a autoridade papal e o começo do movimento protestante. Nesse período, temos quatro concílios, entre eles o Concílio de Trento, talvez, o que mais profundamente influenciou no caminho sinodal da Igreja em todos os tempos. Um dos temas mais discutidos nesse período foi o próprio poder dos concílios, e se esses tinham autoridade maior do que o papa. Esta questão foi chamada de conciliarismo $^{32}$.

Neste contexto, a Igreja que se tornara senhora absoluta do poder no Ocidente, dentro da qual vai residir o próprio poder imperial, vai aos poucos suscitando oposições por parte de reis e príncipes.

\subsection{O reflexo na sinodalidade}

A divisão com o Oriente prejudicou a sinodalidade da Igreja, e como consequências desta divisão pode-se destacar num primeiro momento, como visto no item anterior, o fortalecimento do Papado em detrimento da importância dos sínodos e concílios. Com o forte acento no poder do pontífice romano as reações dos Estados serão imediatas. $\mathrm{Na}$ França, em 1438 se ratificou como lei estatal a teoria conciliar, a proibição de apelar para Roma como última instância, e limitações dos direitos da Santa Sé nas nomeações para ofícios e benefícios na França. Somente em 1905, o papa voltou a nomear os bispos franceses. Na Alemanha, os príncipes usurparam a jurisdição eclesiástica em seus territórios, com a imposição de taxas sobre os bens eclesiásticos. Na Inglaterra, a descrença em relação a Roma se fortaleceu com o cativeiro de Avinhão, quando papa é visto como instrumento do soberano francês; por isso, vários decretos do século XIV negam ao papa o direito de nomeação para os ofícios eclesiásticos ingleses, proíbem o apelo a Roma e a introdução das bulas

32 CONGAR, Y. Église et papauté. Paris: CERF, 2002. p. 59. 
papais. Na Espanha, a unidade religiosa foi considerada básica para a unidade nacional; a inquisição espanhola em 1478 é fruto deste processo. Em 1492, com a conquista da América, Portugal e Espanha adquirem o direito do padroado, pelo qual assumiram o governo da Igreja. Passa-se da comunhão de Igrejas presente em todo o mundo para a uniformização da Igreja, e o esfacelamento do espírito e da prática sinodal.

\section{A sinodalidade eclesial e o enfoque clerical de Trento}

O $13^{\circ}$ Concílio Ecumênico, o Concílio de Trento, ocorrido entre os anos de 1546 a 1563, foi convocado pelo papa Paulo III. As reuniões ocorriam na cidade de Trento, e se estendeu por 18 anos. Foi conduzido por vários papas de acordo com a sucessão: Júlio III, Paulo IV, Pio V, Gregório XIII e Sisto V. Este longo concílio foi concluído somente em 1563. Foram realizadas 25 sessões plenárias, em três períodos diferentes (de 1545 a 1547; de 1551 a 1552; e de 1562 a 1563), quando todas essas sessões foram solenemente promulgadas em sessão pública. Com as decisões do Concílio de Trento a Igreja procura responder aos movimentos da Reforma Protestante iniciados na Europa em 1517. Por isso, muitos historiadores chamam-na de Contrarreforma. É importante destacar que o Concílio de Trento é o ponto alto de toda uma caminhada que tem suas raízes nos séculos IV e V.

O clericalismo encontrou um terreno fértil para se desenvolver, tornando-se causa de obstrução da sinodalidade. Alberigo chama este sistema decorrente de Trento de "tridentinismo"33. Sua organização vai consistir na centralização das instâncias de decisão, supressão de centros de estudos e instauração de colégios de teologia em Roma, centralização da Teologia; aprovação da companhia de Jesus. Segundo Bruno Forte, o sistema de cristandade vai progressivamente impondo uma configuração de dois gêneros na vida eclesial: os clérigos e os leigos. Esta distinção já era testemunhada pela famosa duo genera christianorum, encontrada em Graciano (em 1140), cuja paternidade é atribuída a São Jerônimo: dois são os gêneros de cristãos. O primeiro, ligado ao serviço divino, ligado à contemplação e à oração, abstém-se de todo o barulho das realidades temporais e pertence aos clérigos; o segundo é o dos cristãos pertencente

33 ALBERIGO, G. A Constituição "Gaudium et Spes" no quadro do Concílio Vaticano II. Petrópolis: Vozes, 1965. p. 67. 
aos leigos, ao povo ${ }^{34}$. O Concílio de Trento vai levar a efeito de forma prática e organizacional os pressupostos da reforma gregoriana. A Igreja não só está na mão do clero, como ela se identifica com a hierarquia. A comunidade cristã desaparece e, sempre que se fizer menção à comunhão, deverá ser referida à hierarquia. São sintomáticos a configuração de uma Igreja identificada com a hierarquia, centralizada em Roma, e o desaparecimento dos Sínodos e da Igreja Local.

\section{Sinodalidade e infalibilidade no Vaticano I}

Após trezentos anos da conclusão do Concílio de Trento, mais precisamente no ano de 1864, o papa Pio IX anunciava a um restrito grupo de cardeais da Cúria Romana seu desejo de convocar um concílio ecumênico.

O Concílio Vaticano I (1969-1870) desenrola-se num contexto tenso de violentos ataques à Igreja católica hierárquica, com a consequente postura defensiva e restauradora. Por razões históricas, este concílio não conseguiu levar a cabo toda a tarefa que se propusera, e termina por tratar unilateralmente do poder papal, separado do conjunto da Igreja. Define o Primado do Romano Pontífice e a sua infalibilidade. Pio XII (+1958) termina esse ciclo, insistindo no aspecto de que o Corpo Místico de Cristo se identifica com a Igreja Católica Romana. Nesse modelo, entende-se de maneira unilateral a relação entre Igreja universal e Igreja particular. A tensão entre Igreja universal e particular vive nesse modelo sob a forma de submissão das Igrejas particulares à Igreja de Roma. Esta se parece com a encarnação da única Igreja universal ${ }^{35}$. Não se percebia bem a dialética entre Igreja Local e Universal.

\subsection{O primado de jurisdição}

O primado de jurisdição, definido no Concílio Vaticano I, funcionou na prática como a universalização do modelo da Igreja de Roma, que é uma Igreja particular, impondo suas particularidades a todas as igrejas, inibindo ou até mesmo reprimindo a autonomia das igrejas particulares, no campo da liturgia, de tradições doutrinais, de disciplinas específicas e de tantas outras manifestações de vida das igrejas locais. No imaginário,

34 FORTE, B. A missão dos leigos. São Paulo: Paulinas, 1987.

35 TILLARD, 1986, p. 94-95. 
é como se a Igreja de Roma fosse uma única Igreja, da qual as outras seriam partes subordinadas. Criticando esse modelo, Tillard ${ }^{36}$ afirma que o primado não deveria supor a subordinação dos demais bispos:

E como Pedro não é aquele que "partindo do qual" se edifica a Igreja de Deus, mas aquele que consente ao grupo apostólico de tornar-se, com a própria koinonia na confissão da fé, o autêntico fundamento ( $E f$ 2,20), o bispo de Roma não é aquele "partindo do qual" se edifica a Igreja de Deus, mas aquele que consente ao ministério de seus "irmãos e co-bispos" de desembocar na comunhão de suas igrejas. A missão do bispo da sé apostólica não se coloca acima da missão episcopal enquanto tal, mas no seu seio e ao seu serviço.

Na Constituição Pastor Aeternus, acerca da Igreja, reflete-se, sobretudo, a questão do Primado do Romano Pontífice e propõe-se, como verdade de fé, a infalibilidade papal. Sem uma reflexão sobre o episcopado, a eclesiologia do Vaticano I voltou-se totalmente para a figura do Papa, e colaborou para que o processo de centralização da Igreja, em Roma, se tornasse ainda mais forte. Buscar um "equilíbrio de forças" entre papado e colégio episcopal foi uma das tarefas do Vaticano II $^{37}$. É no quarto capítulo da referida constituição que se tratou da doutrina infalível do Romano Pontífice. Opondo-se a Bossuet e os galicanos que exigiam "o consentimento prévio da Igreja como condição jurídica para a validez do exercício do magistério pontifício", o concílio definiu dogmaticamente a infalibilidade papa ${ }^{38}$. Um dos frutos dessa definição conciliar foi a "grande centralização no governo da Igreja e uma diminuição do poder episcopal dos bispos do orbe". Em Despacho Circular, datado de 1872, mas publicado em 1874, a chancelaria alemã deixa transparecer que as relações entre o Império alemão e o papa foram gravemente hipotecadas pelo Concílio Vaticano I, o que revela o comprometimento do diálogo com a sociedade.

Segundo Comblin, depois do Vaticano I, desde Pio IX os bispos foram ficando cada vez mais controlados pela Cúria e esse movimento atingiu o auge no pontificado de Pio XII (1939-1958) ${ }^{39}$. O clamor por uma prática mais sinodal estava na ordem do dia do Vaticano II. Coube a esse,

36 TILLARD, 1986, p. 138.

37 TILLARD, 1986, p. 47.

38 CODINA, V. Para compreender a eclesiologia a partir da América Latina. São Paulo: Paulinas. 1993. p. 157.

39 COMBLIN, J. et al. Vaticano // 40 anos depois. São Paulo: Paulus, 2006. p. 57. 
quase um século depois, retomar as discussões e trazer à luz princípios como subsidiariedade, corresponsabilidade e colegialidade. A sinodalidade na Igreja Local era em grande medida, a saída para o eclipse dos sínodos e o surgimento das Conferências Episcopais Nacionais. Desde Trento até o Vaticano I se passaram mais de trezentos anos (1546-1869) sem a realização de um sínodo ou concílio no Ocidente.

O centralismo romano foi a grande consequência, fazendo eclipsar a dinâmica sinodal da vida da Igreja. Esse eclipse teve reflexos também na prática dos sínodos diocesanos. Segundo Trichet, em "1742 o arcebispo de Aix diz que em sua diocese faziam quarenta anos que não acontecia um sínodo" ${ }^{40}$. Na constatação do mesmo autor, é no século XVIII que o declínio foi mais evidente. Em vários países se fez esta constatação. $\mathrm{Na}$ Itália as oposições foram fortes por parte de membros da hierarquia; nos países de língua alemã depois de 1750, somente um sínodo diocesano foi celebrado ${ }^{41}$. Mesmo que no próprio Concílio de Trento fosse determinada a prática de sínodos diocesanos e participação de todos os clérigos, que tivessem responsabilidades em paróquias e outros, o desencanto foi relativizando a presença deles. No século XIX somente os coordenadores de regiões e os bispos se faziam presentes. Aos poucos os sínodos foram substituídos por reuniões de coordenadores de região ${ }^{42}$.

\subsection{O Sínodo Diocesano no Código de 1917}

No Código de 1917 o sínodo diocesano está regimentado em sete cânones (356-362). Pode-se encontrar aí a obrigação de celebrar, a frequência, a composição e o objetivo dos sínodos diocesanos. Com a frequência de dez anos, convocado e presidido pelo bispo, tendo a participação do vigário geral, do coordenador de região e de outro padre por ele indicado, representante de comunidade religiosa. Os participantes eram de caráter consultivo. O código de 1917 apresenta-se desestimulador para os que esperavam uma abertura maior à participação dos leigos na vida eclesial ${ }^{43}$. Segundo o autor, de 1919 a 1961, das 87 Dioceses da França, 85 celebraram 85 Sínodos. Nos países de língua alemã, Áustria e Suíça, as 41 dioceses existentes na época foram realizados 79 Sínodos.

\footnotetext{
40 TRICHET, 1992, p. 79.

41 TRICHET, 1992, p. 79.

42 TRICHET, 1992, p. 80.

43 TRICHET, 1992, p. 90-91.
} 
Considera-se uma retomada significativa. A participação nem sempre era fiel ao código de 1917. Em algumas dioceses todo o clero era convocado, outras somente representantes. De acordo com dados consultados os números alternavam entre 57 (Gap 1922) a 386 (Paris 1956). A partir de 1950 algumas dioceses influenciadas pela nova eclesiologia da Igreja Local também mudaram o conteúdo dos sínodos. A ausência dos leigos começa a inquietar muitas Igrejas Locais ${ }^{44}$.

\section{A sinodalidade no Vaticano II}

Falar de sinodalidade no contexto do Concílio Vaticano II é quase que impossível, se não for considerado o conjunto das realidades que foram assumidas pelo próprio Concílio. A palavra sinodalidade como tal não aparece nos documentos conciliares. A sinodalidade que vai emergir no tecido eclesial através dos posicionamentos dos Padres Conciliares, não pode ser encontrada como um tratado restrito a este ou àquele documento, ainda que se possa perceber acentos maiores em um ou outro decreto, constituição ou declaração. A sinodalidade no Concílio Vaticano II está mais para horizonte, semeadura, solo preparado do que para um sistema explícito, acabado, do qual os frutos já estivessem maduros para a colheita. Por ser o concílio um acontecimento preparado ao longo de um caminho, e com uma diversidade de caminhantes, é preciso saber identificar as forças que estão por detrás de cada letra.

Assim, a sinodalidade eclesial precisa ser garimpada no todo, mas sem se perder de vista as "pedras maiores" que serão referência para a busca constante das demais. Alguns dos grandes "pontos de luz" da sinodalidade do Vaticano II podem assim serem apresentados: povo de Deus, mistério, Igreja Local, ministerialidade, serviço, colegialidade, diálogo, missão, história, mistério pascal etc. Todos esses conceitos podem ser integrados no conceito de "Igreja Local", desde onde a sinodalidade pode ser realizada. Como é perceptível, as bases teológicas da reflexão sinodal são amplas e complexas. Recolhem-se aqui alguns aspectos mais eminentes. Elaboram-se neste tópico alguns traços sobre a eclesiologia de comunhão, uma das marcas do Concílio Vaticano $\mathrm{II}^{45}$. A teologia da sinodalidade também é oportuna, juntamente com o questionamento sobre a "democracia na Igreja", um tabu na vida eclesial. É claro que não se

\footnotetext{
44 TRICHET, 1992, p. 97.

45 SEMERARO, 2003, p.15.
} 
refere aqui aos sistemas democráticos de representatividade da sociedade civil e política. Na Igreja se refere ao chamado mesmo de Deus a um povo. Este, na sua totalidade é responsável para ser sinal e como sacramento de Jesus Cristo no mundo. A resistência se fará sentir nos momentos de operacionalizar a instituição dos sínodos e da colegialidade. $\mathrm{O}$ acento será forte na relação entre "poder e primado". Por isso, se pode observar nos últimos pontífices o desejo de rever o exercício do primado na Igreja.

\section{1 "Mistério" e "povo de deus" na sinodalidade eclesial}

Conforme Lumen Gentium 4 (LG 4) ${ }^{46}$, na eclesiologia conciliar a Igreja é apresentada como "povo congregado na unidade do Pai e do Filho e do Espírito Santo", que caminha nas estradas do mundo sendo "sacramento [...], sinal e instrumento, da união íntima com Deus e da unidade de todo o gênero humano [...]" $(L G 1)^{47}$. Esse é o povo "constituído por Cristo numa comunhão de vida, de caridade e de verdade. É também assumido por ele para ser instrumento da redenção universal, e como luz do mundo e sal da terra (Mt 5,13-16), e enviado ao mundo inteiro" $(L G 9)^{48}$. A Igreja como mistério, à imagem da Trindade, é chamada a viver em comunhão. Como o mandato missionário de Jesus Cristo se dirige a todos os batizados, é desejo do Senhor que a hierarquia conte com a colaboração de um laicato autêntico em seu empenhado esforço pela evangelização $(A G 21)^{49}$. Na Constituição Apostólica "Sacrae disciplinae leges", recorda João Paulo II: entre os principais elementos que caracterizam, de acordo com o Concílio Vaticano II, a verdadeira e genuína imagem da Igreja está "a doutrina, segundo a qual a Igreja é apresentada como "Povo de Deus" e a autoridade hierárquica é proposta como serviço; a doutrina segundo a qual a Igreja é vista como 'comunhão' e que, portanto, determina as relações que devem existir entre as Igrejas particulares e a Igreja universal, e entre a colegialidade e o primado; a doutrina, por outro lado, segundo a qual todos os membros do Povo de Deus, no modo próprio a cada um, são participantes do tríplice múnus de

46 Lumen Gentium, 4. In: Compêndio do Vaticano II: Constituições, decretos e declarações. Petrópolis: Vozes, 1991. p. 41.

47 LG, 1, 1991, p. 39.

$48 \quad$ LG, 9, 1991, p. 48-50.

49 Ad Gentes, 21. In: Compêndio do Vaticano II: Constituições, decretos e declarações. Petrópolis: Vozes, 1991. p. 378. 
Cristo: sacerdotal, profético e régio" ${ }^{50}$. Para levar a efeito este princípio de comunhão na Igreja visível, o Concílio propõe a realização de sínodos diocesanos $(\mathrm{CD}, 36)$. Compreende-se que, em sua regulamentação pelo Código de Direito Canônico de 1983, o enfoque será institucional. Porém, é preciso avançar para um processo mais participativo de todo o Povo de Deus.

\subsection{A sinodalidade na Igreja Local}

Ao seguir o caminho do Vaticano II do "retorno às fontes", quer seja na Sagrada Escritura ou nos Padres da Igreja, a redescoberta da "Igreja Local" na perspectiva da eclesiologia do "Povo de Deus" foi o grande resgate ainda por ser devidamente implementado. Na Igreja Local se radica e se manifesta tanto a Igreja mistério de comunhão ( $L G 1$ a 8 : cap. I) como a Igreja povo de Deus ( $L G 9$ a 17: cap. II) e nesta, a colegialidade episcopal de base sacramental, inserida na sinodalidade da Igreja, os demais ministérios, a comunhão com o bispo de Roma e o serviço da cúria romana, a emergência do laicato como sujeitos e corresponsáveis na missão da Igreja etc. Tudo vai interpelar uma reconfiguração das instituições eclesiásticas com as necessidades da renovação eclesiológica. As próprias conferências episcopais foram adquirindo maior vigor justamente no período em que começa a surgir uma inovação na reflexão eclesiológica, pontuando as Igrejas Locais desde o horizonte de porção do Povo de Deus tendo no centro o bispo diocesano que, ligado aos demais bispos e ao bispo de Roma, preside a comunidade eucarística na condição de verdadeiro sucessor dos apóstolos. O Concílio Vaticano II garimpa esta riqueza, situando na experiência da Igreja neotestamentaria e dos primeiros séculos, a interrelação da colegialidade (Conferências Episcopais) com a sinodalidade (Sínodos-Concílios) de âmbitos: local, regional e ecumênico. A "sinodalidade na Igreja Local" assinala um caminho feito de baixo para cima.

\section{Conclusão}

Concluindo esse artigo, é preciso que se diga que, num espírito sinodal as Igrejas Locais poderiam ampliar a participação do Povo de Deus em suas histórias. O Papa Francisco acena nesta direção, mas é

$\overline{50}$ ACTA APOSTOLICAE SEDIS, 89, 1997. p. 706-707. 
preciso um empenho maior do episcopado, dos padres e dos leigos. A base batismal precisa ser mais refletida na operacionalidade da Igreja. Porém, tem-se que reconhecer o caminho percorrido.

\section{Referências bibliográficas}

CABALLERO, José. El Sínodo Diocesano: breve recorrido a sua actuacion y evolucion histórica. Ius Canonicum, Pamplona, v. 21, n. 42, p. 543-566, 1981.

CLERCQ, Charles de. Histoire de Conciles d'après les documents originaux. Paris: Librairie Lrtouzey et Ané. 1949. t.11.

CHIRON, Yves. Histoire des conciles. Paris: Pérrin, 2011.

CODINA, Vitor. Para compreender a eclesiologia a partir da América Latina. São Paulo: Paulinas. 1993.

COMBLIN, José. Vocação para a liberdade. São Paulo: Paulus, 1998. . O Povo de Deus. São Paulo: Paulus, 2002.

COMPÊNDIO DO VATICANO II: Constituições, decretos e declarações. Petrópolis: Vozes, 1991.

DANIÉLOU, Jean. Des origines à la fin du troisième siècle. In: ROGIER, L. J.; AUBERT, R.; KNOWLES, M. D. Nouvelle histoire de l'Eglise, I. Paris: Du Seuil, 1963. p. 139-140.

FORTE, Bruno. A missão dos leigos. São Paulo: Paulinas, 1987.

HEFELE, Karl J.; LECLERCQ, H. Histoire des Conciles, d'après les documents originaux. Paris: Librairie Lrtouzey et Ané, 1907. t. 4.

GHIRLANDA, Gianfranco. O Direito na Igreja: mistério de comunhão: compêndio de direito eclesial. Aparecida: Santuário, 2003.

LIMA, L. Alves de. Sínodo dos bispos. In: Dicionário do Vaticano II. São Paulo: Paulinas; Paulus, 2015. p. 910.

MOGAVERO, Domenico. Il Sinodo Diocesano. In: LONGHITANO, A. et al. Chiesa Particulare e strutture di comunione. Bologna: EDB, 1985.

PAIVA, José. P. Sínodos diocesanos. I Época medieval e moderna. In: AZEVEDO, C. (Ed.). Dicionário de história religiosa de Portugal IV. Lisboa: Círculo de Leitores, 2000. p. 240-241. 
SEMERARO, Marcello. Sínodo. In: Lexicon: dicionário teológico enciclopédico. São Paulo: Loyola, 2003.

TILLARD, Jean. M. El obispo de Roma: studio sobre el papado. Madrid, España: Sal Terrae, 1986. p. 19-20. (Col. Presencia teológica, 33). 1987. . Église d'église: L'écclésiologie de communio. Paris: CERF,

TRICHET, Louis. Le Synode Diocesain. Paris: Cerf, 1992.

VANIER, Anne M. Les pères et la naissence de l'ecclésiologie. Paris. CERF, 2009.

ZITO, Gaetano. La figura del vescovo lungo i secoli. Profilo storico fino al Concilio Vaticano I. In: PERI, V. (Ed.). La comunione con il vescovo. Profili storici, biblici, teologici. Roma: Unione Apostolica del Clero, 2009. p. 16. 